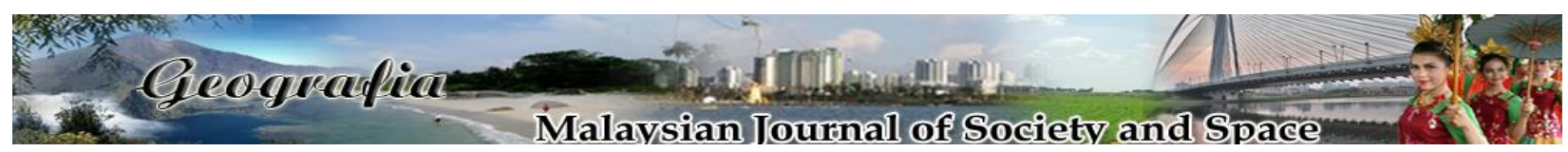

\title{
Penyertaan orang Asli dalam aktiviti eko-pelancongan di Tasik Chini, Pahang, Malaysia
}

\author{
Zanisah Man ${ }^{1}$, Yeoh En $\mathrm{Ne}^{2}$ \\ ${ }^{1}$ Program Antropologi dan Sosiologi, Pusat Pembangunan, Sosial dan Persekitaran, \\ Fakulti Sains Sosial dan Kemanusian, Universiti Kebangsaan Malaysia \\ ${ }^{2}$ AJK Kampung Melai, Tasik Chini \\ Correspondence: Zanisah Man (email: zanisahman@ukm.edu.my)
}

Received: 21 November 2018; Accepted: 29 July 2019; Published: 25 November 2019

\begin{abstract}
Abstrak
Transformasi ekonomi global dan lokal yang menjurus kepada sektor perindustrian dan teknologi bagi tujuan pembangunan ekonomi telah mengakibatkan komuniti minoriti seperti orang asli untuk tidak boleh lagi hanya bergantung kepada hasil hutan sebagai sumber pendapatan. Sehubungan itu komuniti Orang Asli daripada suku Jakun di Tasik Chini, Pahang telah melibatkan diri secara aktif dalam aktiviti pelancongan dengan menubuhkan rumah penginapan seperti Kijang Mas Gumum Chalet, Rajan Jones Guest House dan Wira Gumum Resorts atas modal persendirian dan bantuan kerajaan. Temubual mendalam dengan bekas dan pengusaha rumah tumpangan serta pemimpin tempatan telah dilakukan bagi mengenalpasti cabaran pelancongan di Tasik Chini. Data yang diperolehi daripada ketua atau wakil isirumah di lima buah kampung Orang Asli pada tahun 2017 telah dibandingkan dengan data Pelan Strategik Tasik Chini pada tahun 2010 bagi melihat pergantungan komuniti terhadap sumber semulajadi di Tasik Chini. Kajian mendapati, penyertaan komuniti Jakun dalam program eko-pelancongan termasuk penjagaan dan pemuliharaan alam sekitar adalah sangat positif. Akan tetapi, kesediaan Tasik Chini untuk menawarkan sebuah destinasi pelancongan yang mampu menarik perhatian pelancong dari dalam dan luar negara semakin ampuh disebabkan oleh kemerosotan alam sekitar yang semakin meruncing. Kesiapsiagaan komuniti Jakun dalam mengendalikan aktiviti pelancongan dan isu pemilikan tanah bagi tapak pelancongan juga menjadi cabaran utama keberdayasaingan eko-pelancongan di kawasan ini. Oleh itu, kajian ini mencadangkan supaya kerjasama antara komuniti dan agensi-agensi yang berwibawa amat perlu untuk menangani masalah alam sekitar di Tasik Chini. Aktiviti eko-pelancongan yang berasaskan kebudayaan Orang Asli serta berunsurkan konsep homestay dan kampungstay perlu dilaksanakan bagi meningkatkan kembali minat pelancong ke kawasan ini.
\end{abstract}

Katakunci: orang Asli, eko-pelancongan orang asli, penglibatan orang Asli, Tasik Chini, kemerosotan alam sekitar 


\title{
Orang Asli participation in eco-tourism activities at Tasik Chini, Pahang, Malaysia
}

\begin{abstract}
The global and local economic transformation leading to the industrial and technological sectors for economic development have resulted in the minority community such as the indigenous people cannot only rely with forest products for their sources of income. This situation has led the Orang Asli of Jakun community in Tasik Chini to actively involved in tourism industry with the establishment of Kijang Mas Gumum Chalet, Rajan Jones Guest House and Wira Gumum Resorts, operated under personal funding and government assistance. In-depth interview was conducted with former and recent chalet operators, and local leaders in order to understand the tourism struggles in Tasik Chini. Data collected from the head households or their representatives from five villages in 2017 were compared with 2010's Tasik Chini Strategik Implementation Plan in order to see the the community's dependency on the natural resources surrounding Tasik Chini. The findings showed a positive engagement of Jakun community towards eco-tourism programs including the protection and conservation of the natural environment. However, Tasik Chini readiness as an attractive tourist destination viewed by both locals and foreign visitors is increasingly hampered by the existing environmental degradation. Likewise, community preparedness in terms of conducting their eco-tourism activities, and issues related to land ownership within the touristic sites have become the major challenges to the competitiveness of the eco-tourism in this area. For that reason, collaboration between all stakeholders such as the local community and other agencies is essential in order to tackle the environmental issues enveloping Tasik Chini. Initiating eco-tourism activities inspired by Orang Asli culture and focusing on homestay and kampungstay concepts is necessary, in order to restore the tourist's attraction within this area.
\end{abstract}

Keywords: orang Asli, indigenous ecotourism, indigenous participation, Tasik Chini, environmental degradation

\section{Pengenalan}

Perkembangan ekonomi negara yang pesat semenjak kerajaan memperkenalkan Dasar Ekonomi Baru (DEB) pada tahun 1970an telah mengubah corak ekonomi Malaysia secara keseluruhannya. Penerokaan dan penebangan hutan untuk tujuan pertanian telah dilakukan secara intensif bagi menyahut seruan kerajaan untuk membasmi kemiskinan dan menyatu-padukan rakyat. Ekonomi pertanian ini kemudiannya berubah kepada ekonomi berteraskan perindustrian bagi menjadikan Malaysia sebuah negara maju yang berpendapatan tinggi untuk mencapai Transformasi Nasional 2050. Dalam transformasi ini, kerajaan sedang berusaha untuk membentuk aspirasi Malaysia yang diambil daripada pelbagai lapisan termasuk komuniti minoriti Orang Asli. Di samping itu, produk eko-pelancongan juga diberikan keutamaan yang besar bagi menjayakan aspirasi negara untuk memperkukuhkan pertumbuhan ekonomi Malaysia yang terkandung dalam teras ke-enam Rancangan Malaysia ke-11 pada tahun 2018 (Kementerian Hal Ehwal Ekonomi, 2018) 
Dewasa ini, komuniti Orang Asli tidak lagi mampu bergantung kepada ekonomi sara diri berasaskan sumber hutan sepenuhnya bagi menjalani kehidupan harian mereka. Meskipun terdapat komuniti yang berusaha untuk mengekalkan budaya tradisi misalnya komuniti Batek di Taman Negara, namun hutan yang semakin berkurangan, peningkatan penduduk dan sumber makanan yang semakin meruncing menyebabkan sistem ekonomi sara diri seperti mendapatkan ubi liar dan memburu binatang tidak dapat dilakukan dengan lebih kerap. Justeru, terdapat sebilangan kecil komuniti Batek yang beralih kepada ekonomi pelancongan dan bekerjasama dengan kumpulan pemandu pelancong Melayu daripada Kuala Tahan untuk menubuhkan dan mengerakkan Bateq Jungle Hut dalam kawasan perkampungan mereka di Dedari bagi tujuan menjana pendapatan tambahan (Zanisah Man et al., 2009; Zanisah Man \& Sharina Halim, 2018). Selain itu, Gomes (1989) dalam kajiannya ke atas komuniti Orang Asli dari suku Semai di Perak menyatakan bahawa ekonomi komuniti ini telah berubah daripada ekonomi sara diri iaitu mendapatkan makanan atau sumber hutan untuk kegunaan keluarga kepada menjual hasil hutan bagi mendapatkan wang tunai untuk membeli barangan keperluan keluarga seperti beras. Hasilnya, majoriti Orang Asli beralih kepada tanaman kontan atau tanaman makanan yang mempunyai nilai di pasaran. Walaupun demikian, sistem ekonomi seumpama ini tidak begitu memihak kepada komuniti Orang Asli kerana ia berubah mengikut pasang dan surutnya permintaan terhadap komoditi tertentu. Jualan durian, petai atau katak misalnya berubah mengikut musim dan keperluan. Para pemborong atau 'taukeh' Cina juga seringkali menetapkan harga yang rendah bagi setiap item yang dibeli dengan alasan untuk menampung kos pengangkutan dan jarak petempatan yang jauh daripada bandar.

Usaha kerajaan menyediakan kemudahan asas misalnya jalan raya di dalam perkampungan Orang Asli telah meningkatkan akses mereka kepada dunia luar. Situasi ini telah menggalakkan penyertaan komuniti Orang Asli secara langsung di dalam ekonomi berasaskan produk dan perkhidmatan pelancongan terutamanya di kawasan yang mempunyai daya tarikan semulajadi seperti Taman Negara, Tasik Chini dan Tasik Bera di Pahang. Selain keindahan alam sekitar, antara tarikan pelancongan yang ditawarkan meliputi kebudayaan, kesenian dan lawatan perkampungan Orang Asli. Zeppel (2006) menakrifkan pelancongan seumpama ini sebagai Indigenous Eco-tourism yang meliputi tarikan semulajadi atau apa sahaja bentuk pelancongan yang dimiliki oleh Orang Asli, yang menonjolkan amalan dan budaya tradisi mereka serta hubungannya dengan tanah atau tempat kediaman (alam sekitar) mereka. Penyertaan komuniti dalam pelancongan menurut Harris (2005) telah berjaya membangunkan mereka dalam aspek pemerkasaan komuniti, pembangunan, kesihatan dan pembelajaran. Dalam erti kata lain, penglibatan komuniti Orang Asli suku Jakun di Tasik Chini adalah signifikan dan amat penting dalam menjayakan pelancongan yang berteraskan konsep alam sekitar ini. Bagi eko-pelancongan berteraskan komuniti, Gezon (2014), berpendapat bahawa penilaian kesan eko-pelancongan dan pentaksiran terhadap kapisiti dan keupayaan komuniti tempatan juga perlu dilakukan ke atas sesuatu tapak eko-pelancongan yang sedang atau telah dibangunkan. Oleh itu, artikel ini bertujuan untuk menyelusuri sejarah penglibatan dan penyertaan komuniti Jakun dalam aktiviti pelancongan di Tasik Chini, situasi semasa alam sekitar dan cabaran kesan pelancongan ke atas komuniti Jakun yang menetap di kawasan tersebut. 


\section{Aktiviti pelancongan dan keadaan semasa alam sekitar di Tasik Chini}

Komuniti Orang Asli suku Jakun di Tasik Chini telah terdedah kepada pelancongan semenjak tahun 1970an dengan kemasukan pelancong asing yang ingin melihat keindahan Tasik Chini dan dalam masa yang sama bertujuan untuk membuat penyelidikan runtuhan Mon Khmer di kawasan ini (Wavell, 1988). Pada tahun 1990an, aktiviti pelancongan di Tasik Chini semakin rancak dengan aktiviti kayak nasional yang bermula dari Tasik Bera ke Tasik Chini. Penganjuran program pelancongan seumpama ini seiring dengan perlaksanaan Tasik Bera sebagai Tapak Ramsar dunia pada tahun 1994 (Mokbolhassan, 2014). Walaupun begitu, aktiviti pelancongan pada masa tersebut dikendalikan sepenuhnya oleh komuniti Melayu di Kampung Belimbing yang tinggal di pesisiran Sungai Pahang. Manakala komuniti Jakun di Tasik Chini pula merupakan komuniti penerima sahaja dan tidak terlibat secara aktif. Penglibatan aktif komuniti Jakun di Tasik Chini bermula di sekitar penghujung 1990an dengan pembinaan rumah penginapan dalam kawasan perkampungan mereka iaitu di Gumum. Pada tahun 2009, Program Man and Biosphere (MAB) di bawah UNESCO dengan kerjasama Pusat Penyelidikan Tasik Chini (PPTC), Universiti Kebangsaan Malaysia telah ditubuhkan di Tasik Chini dengan tujuan untuk menyokong konsep pembangunan eko-pelancongan yang lestari dengan melibatkan penduduk yang berhampiran dalam penjagaan dan pemuliharaan alam sekitar. Penglibatan komuniti Jakun dalam aktiviti penjagaan dan pemuliharaan alam sekitar Tasik Chini melalui penubuhan Persatuan Pelindung Tasik Chini juga menunjukkan usaha dan kesedaran penduduk tempatan tentang kepentingan menjaga alam sekitar di kawasan mereka (Sustainable Development Network Malaysia, 2007).

Kemerosotan alam sekitar di Tasik Chini pada awalnya dikaitkan dengan pembinaan kincir air atau dikenali juga sebagai empangan atau dam oleh penduduk setempat. Kincir air ini dibina pada tahun 1990an dengan tujuan untuk meningkatkan paras air di dalam tasik bagi memudahkan laluan bot yang digunakan dalam aktiviti pelancongan. Laluan bot menyusuri Sungai Chini dari Kampung Belimbing pada masa tersebut agak sukar disebabkan air yang cetek terutamanya pada musim kemarau. Pemandu bot terpaksa mengambil masa beberapa jam untuk sampai ke Tasik Chini, bergelumang dengan lumpur bagi menarik bot terutamanya di kawasan yang cetek.

Selepas pembinaan kincir air, kemerosotan alam sekitar di kawasan Tasik Chini mula dirasakan dengan kemusnahan pokok-pokok di sekitar tebing sungai dan tasik yang terhasil akibat daripada peningkatan paras air di dalam tasik. Peningkatan paras air juga menyebabkan habitat teratai yang merupakan tarikan pelancongan di Tasik Chini semakin berkurangan. Keadaan in diburukkan lagi oleh penerokaan dan pembukaan tanah secara intensif di kawasan sekitar Tasik Chini untuk pembalakan dan perlombongan bijih besi yang menyebabkan hakisan dan seterusnya meningkatkan pemendapan tanah di dalam tasik. Kajian pada tahun 2009 menunjukkan bahawa pemendapan di dalam kawasan Tasik Chini adalah lebih tinggi berbanding dengan Sungai Chini (Muhammad Barzani Gasim et al. 2009).

Aliran baja pertanian ke dalam tasik telah menyebabkan masalah eutrofikasi iaitu keadaan di mana kemasukan nutrien yang berlebihan terutama fosforus ke dalam jasad air daripada buangan pertanian dan kumbahan (Mohd Shuhaimi Othman \& Lim, 2004) dan seterusnya menggangu keadaan semulajadi tasik. Kemasukan nutrien yang berlebihan menggalakkan peningkatan tumbuh-tumbuhan ekor kucing (Cabomba furcata) di dalam kawasan tasik. Tumbuhan ekor kucing dipercayai merupakan tumbuhan asing yang dibawa dari luar Tasik Chini. Akibatnya, kawasan Tasik Chini pada masa kini telah dikuasai oleh tumbuh-tumbuhan ini 
dan menjadi pesaing kepada tumbuhan akuatik yang lain seperti teratai yang tumbuh secara semulajadi di kawasan Tasik Chini.

Kajian oleh Universiti Kebangsaan Malaysia pada tahun 2009 menunjukkan terdapat bakteria fecal colifom yang tinggi di dalam air telaga (Ainon Hamzah \& Yanti Hattasrul, 2009). Fecal colifom ialah bakteria yang terdapat pada tahi manusia. Bakteria ini boleh memasuki badan manusia melalui mulut, hidung, telinga atau luka pada kulit dan seterusnya boleh menyebabkan demam, muntah atau sakit perut. Penyakit yang dikaitkan dengan bakteria ini ialah demam kepialu (typhoid fever), hepatitis, radang perut/usus (gastroenteritis), cirit-birit (dysentry) dan jangkitan telinga. Walaupun begitu, bakteria ini juga boleh dibunuh melalui cara memasak air dan menggunakan rawatan klorin. Air telaga dan tasik menunjukkan kualiti pada paras I-III (Rujuk Jadual 1) bergantung kepada kawasan (Mohd Shuhaimi Othman et al., 2009; Ainon Hamzah \& Yanti Hattasrul, 2009).

\section{Lokasi kajian}

Tasik Chini merupakan sebuah tasik semulajadi kedua terbesar di Malaysia selain daripada Tasik Bera. Tasik ini terletak di dalam Mukim Penyor, daerah Pekan, negeri Pahang. Pada waktu dahulu, terdapat enam buah perkampungan kecil yang dikenali sebagai Kampung Gumum, Kampung Ulu Gumum, Kampung Cendahan, Kampung Tanjung Puput (dikenali juga sebagai Kuput atau Puput), Kampung Melai (Melai dan Pantai Melai) dan Kampung Ulu Melai. Penebangan hutan daripada pembalakan dan perlombongan bijih besi yang intensif sejak tahun 2012 telah menyebabkan sempadan hutan kecil yang memisahkan di antara kampung Ulu Melai dan Kampung Melai telah terhapus. Oleh itu, kedua-dua kampung Ulu Melai dan Melai ini telah menjadi satu dan dikenali sebagai kampung Melai. Sehingga kini, terdapat 5 buah perkampungan kecil di Tasik Chini iaitu Gumum, Ulu Gumum, Cendahan, Tanjung Puput dan Melai yang dihuni oleh 761 penduduk yang terdiri daripada 231 ketua isirumah Orang Asli daripada majoriti suku kaum Jakun (JKKK Tasik Chini, 2017). Kebanyakan penduduk Jakun di Tasik Chini bekerja sebagai penoreh getah dan peneroka kelapa sawit di bawah rancangan RISDA. Sebilangan kecil penduduk terlibat dalam aktiviti pelancongan seperti pengusaha chalet, pemandu pelancong, pemandu bot dan menjual kraftangan, pengumpulan hasil hutan seperti rotan dan tumbuh-tumbuhan ubatan dan aktiviti sampingan bergaji hari seperti menebas kebun dan menanam sayur-sayuran.

\section{Kaedah kajian}

Dalam kajian ini, sejarah penglibatan komuniti Jakun di Tasik Chini telah diperolehi melalui kajian kualitatif iaitu temubual mendalam dengan beberapa informan utama yang terdiri daripada pengusaha/bekas pengusaha rumah penginapan (Rajan Jones Guest House, bekas pengurus Kijang Mas Gumum Chalet dan pengusaha Wira Gumum Resorts), pemimpin setempat dan individu yang terlibat secara langsung dengan pelancongan di Tasik Chini seperti pemandu bot, pengerusi Pertubuhan Pelindung Tasik Chini, batin selaku ketua masyarakat dan pengusaha kraftangan yang terdiri daripada komuniti Jakun. Maklumat daripada Koperasi Kijang Mas dan Lake Chini resort tidak dikumpul dalam kajian ini kerana ia lebih memberi fokus kepada penglibatan komuniti Jakun. Manakala kajian kuantitatif telah dilakukan pada bulan Oktober dan 
November 2017 dengan memberi fokus kepada 45 ketua isirumah (KIR) atau wakil KIR bagi tiga buah perkampungan utama berhampiran dengan Tasik Chini iaitu Kampung Melai, Tanjung Puput dan Cendahan. Selain itu, kajian terhadap pergantungan sumber penduduk pada tahun 2010 yang terkandung dalam Strategik Implementation Plan Comprising of Integrated Management Plan and Gazettement of Tasik Chini State Park, Pekan Pahang Volume 3 (2010) telah dijadikan asas untuk melihat perbezaan kebergantungan penduduk Tasik Chini terhadap alam sekitar dahulu dan pada masa kini. Perbandingan ini adalah penting untuk melihat kesan alam sekitar dan penglibatan komuniti Orang Asli dalam eko-pelancongan. Analisis data statistik menggunakan perisian Statistical Package for Social Sciences (SPSS) telah dipersembahkan dalam bentuk jadual silang yang ringkas. Manakala data naratif daripada temubual telah dikategorikan mengikut tema-tema yang spesifik.

\section{Hasil kajian dan perbincangan}

Sejarah penglibatan komuniti Jakun dengan aktiviti pelancongan di Tasik Chini

Berdasarkan data yang diperolehi daripada temubual lapangan, penglibatan aktif penduduk Jakun Tasik Chini dalam aktiviti pelancongan dianggarkan bermula pada tahun 1990an. Pada tahun 1997, Koperasi Kijang Mas telah mengisi tanah kosong yang dimiliki oleh penduduk tempatan berhampiran jeti di Kampung Gumum dengan memulakan pembinaan 10 chalet dan dua asrama yang dikenali sebagai Kijang Mas Gumum Chalet untuk disewakan kepada para pelancong. Pada awalnya, chalet ini beroperasi menggunakan air telaga yang dipam masuk menggunakan enjin sebelum kemudahan asas elektrik dan paip air disalurkan kemudiannya. Kijang Mas telah melantik seorang penyelia wanita Orang Asli dari Kampung Gumum untuk menguruskan pentadbiran dan perkhidmatan operasi chalet ini pada tahun 1998. Penglibatan wanita Orang Asli ini yang berterusan dalam operasi Kijang Mas telah menimbulkan minat dan kecenderungan beliau untuk terlibat lebih mendalam di dalam perniagaan berasaskan pelancongan ini. Oleh itu, pada tahun 2000, permohonan dibuat untuk menyewa Kijang Mas Gumum Chalet daripada pihak Koperasi Kijang Mas. Permohonan tersebut telah diluluskan dan semasa penglibatannya pada tahun 2001-2002, kedatangan pelancong adalah ramai dan kebanyakannya daripada Perancis, Belanda, Amerika, Singapura, Jepun, Korea dan segelintir daripada negara Arab.

Kejayaan pengusaha wanita ini telah menarik minat penduduk kampung yang lain untuk menceburkan diri dan ikut serta dalam perniagaan pelancongan. Justeru, sebuah rumah penginapan yang lain telah dibina sekitar tahun 2003 dan dinamakan Wira Gumum Resorts atas inisiatif anak tempatan komuniti Jakun di Kampung Gumum sendiri dan menggunakan sumber kewangan persendirian. Namun begitu, rumah penginapan ini tidak dapat bertahan lama disebabkan kekurangan pelancong dan persaingan yang tinggi dengan Kijang Mas Gumum Chalet dan Rajan Jones Guest House yang telah lama bertapak di perkampungan ini. Selain itu, masalah kekurangan tenaga mahir dalam pentadbiran dan pengurusan juga telah merencatkan perkembangan rumah penginapan ini.

Dalam masa yang sama, Kijang Mas Gumum Chalet juga menghadapi masalahnya yang tersendiri. Kekurangan modal pusingan menyebabkan aktiviti chalet ini tidak dapat diteruskan. Oleh itu, pada tahun 2004, usahawan wanita Orang Asli di Tasik Chini terpaksa menutup perniagaan beliau dan Kijang Mas Gumum Chalet telah diambil alih pengurusannya oleh seorang pengusaha Melayu daripada Kampung Salong, Pahang. Namun begitu, penurunan bilangan 
pelancong telah menyebabkan hanya satu tahun sahaja aktiviti chalet ini dapat dijalankan. Oleh itu, Kijang Mas Gumum Chalet hanya tinggal runtuhan bangunan dan dipenuhi semak samun. Manakala sebahagian daripada rumah penginapan Wira Gumum Resorts telah diubahsuai dan dihuni oleh penduduk tempatan sebagai rumah kekal mereka. Hanya rumah tumpangan milik pengusaha India yang telah berkahwin dengan masyarakat Orang Asli tempatan dan menetap di Kampung Gumum iaitu Rajan Jones Guest House sahaja yang masih kekal dan beroperasi sehingga sekarang meskipun pemilik asalnya iaitu Encik Rajan telah meninggal dunia.

Pada awalnya, Rajan Jones Guest House menyediakan dua buah rumah penginapan yang mempunyai suasana yang berbeza iaitu terletak di dalam kawasan perkampungan dan berhampiran dengan Tasik Chini. Rumah penginapan yang terletak dalam kawasan perkampungan merupakan sebuah rumah papan yang dibahagikan kepada sepuluh buah bilik kecil. Setiap bilik ini dilengkapi dengan tilam dan kelambu dan juga mempunyai kemudahan asas seperti elektrik dan air yang diambil daripada punca air telaga. Manakala penginapan kedua yang berlatarbelakangkan Tasik Chini lebih mirip kepada rumah tradisional dan kehidupan masyarakat Orang Asli namun telah ditutup semenjak beberapa tahun yang lepas. Kebanyakan pelancong yang berkunjung di Rajan Jones Guest House adalah terdiri daripada pelancong luar negara yang datang bercuti atau pun pelancong akademik. Rajan Jones Guest House juga mengalami masalah kekurangan pelancong yang datang mengikut musim dan persaingan dengan Lake Chini Resort, sebuah resort pelancongan milik kerajaan yang mempunyai kemudahan prasarana yang jauh lebih baik. Malah, pakej jungle trekking di bawah Rajan Jones Guest House juga tidak lagi ditawarkan di kawasan-kawasan tertentu disebabkan oleh penebangan hutan untuk tujuan pembalakan misalnya di kampung Melai. Malah penyelenggaraan laluan jungle trekking juga terhenti selepas mendiang Uncle Rajan iaitu pemilik Rajan Jones Guest House mula jatuh sakit pada tahun 2010.

Namun demikian, Lake Chini Resort juga masih menjalinkan hubungan kerjasama dengan penduduk kampung di Tanjung Puput dan Cendahan yang menawarkan konsep budaya Orang Asli sebagai tontonan pelancong. Kedua-dua kampung ini mengekalkan konsep kampung budaya dan mempamerkan hasil kraftangan Orang Asli untuk dijual kepada para pelancong yang datang berkunjung. Kadangkala penduduk dari Kampung Gumum juga turut serta dalam industri kraft dengan menghantar hasil kraftangan mereka untuk dijual di tempat pameran yang telah disediakan oleh kerajaan di Kampungg Puput dan Cendahan.

\section{Cabaran Pelancongan di Tasik Chini}

Terdapat tiga elemen cabaran yang telah dikenalpasti dalam membangunkan aktiviti pelancongan di Tasik Chini iaitu cabaran membangunkan kesediaan Tasik Chini sebagai destinasi pelancongan, membina kesiapsiagaan komuniti Jakun dalam aktiviti pelancongan dan mengurus isu berkaitan hakmilik tanah.

a. Kesediaan Tasik Chini sebagai sebuah destinasi pelancongan

\section{Tarikan keindahan alam semulajadi dan penjanaan ekonomi}

Umumnya, antara cabaran utama dalam industri pelancongan ialah keupayaan untuk menarik para pelancong yang bertandang buat pertama kali untuk membuat kunjungan susulan. Ini 
disusuli dengan penyebaran tentang keindahan dan keunikan tempat tersebut kepada kenalan atau masyarakat luar yang lain. Keupayaan untuk menarik pelancong ini semakin berkurangan di Tasik Chini kerana penerokaan hutan untuk aktiviti pertanian, perlombongan dan pembalakan telah mengubah ekosistem dan keseimbangan alam sekitar di kawasan ini. Perubahan ini sangat dirasakan oleh komuniti Jakun yang telah menetap di sini semenjak tahun 2010 lagi. Sebahagian besar (83.1\%) komuniti Jakun di Tasik Chini pada tahun 2010 mengakui tidak lagi menggunakan kawasan hutan Tasik Chini sebagai kawasan rekreasi/hiburan mereka (Lihat Jadual 3). Hanya segelintir (10.4\%) yang masih aktif menggunakan kawasan tasik pada tahun 2010 sebagai tempat rekreasi seperti berkelah dan memancing.

Jadual 3. Fungsi tasik dan kawasan hutan tahun 2010

\begin{tabular}{lcccccc}
\hline \multirow{3}{*}{$\begin{array}{l}\text { Jenis keperluan/perolehan aktiviti } \\
(\boldsymbol{\Sigma} \mathbf{n}=\mathbf{7 9 )}\end{array}$} & \multicolumn{3}{c}{ Tasik/Sungai } \\
\cline { 2 - 7 } & $\begin{array}{c}\text { Tidak } \\
\text { pernah } \\
(\boldsymbol{\%})\end{array}$ & $\begin{array}{c}\text { Kadangkala } \\
(\boldsymbol{\%})\end{array}$ & $\begin{array}{c}\text { Kerap } \\
(\boldsymbol{\%})\end{array}$ & $\begin{array}{c}\text { Tidak } \\
\text { pernah } \\
(\boldsymbol{\%})\end{array}$ & $\begin{array}{c}\text { Kadangkala } \\
(\boldsymbol{\%})\end{array}$ & $\begin{array}{c}\text { Kerap } \\
(\boldsymbol{\%})\end{array}$ \\
\hline Bekalan hasil kraftangan & 84.4 & 9.1 & 6.5 & 57.1 & 16.9 & 26.0 \\
Sumber pekerjaan berkait pelancongan & 92.2 & 5.2 & 2.6 & 94.8 & 3.9 & 1.3 \\
Sumber rekreasi /hiburan & 77.9 & 11.7 & 10.4 & 83.1 & 9.1 & 7.8 \\
\hline
\end{tabular}

Sumber: Strategik Implementation Plan Comprising of Integrated Management Plan and Gazettement of Tasik Chini State Park, Pekan Pahang Volume 3 (2010: Chapter 4-11).

Kajian terkini menunjukkan hanya 9.09 peratus (Jadual 4) penduduk yang terlibat secara aktif dan sampingan dalam aktiviti pembuatan kraftangan dan majoritinya disumbang oleh komuniti Jakun yang tinggal di kampung Tanjung Puput. Permintaan berkala hasil hutan seperti madu kelulut, kayu kayan, rotan dan herba telah menyumbang kepada ekonomi komuniti Jakun khususnya di kampung Melai. Faktor alam sekitar seperti pembalakan dan perlombongan telah mengubah landskap Tasik Chini dan menyumbang kepada kemerosotan pelancong yang ketara. Akibatnya, aktiviti perlancongan berkaitan alam sekitar di Tasik Chini semakin merosot dan mendorong pemandu bot serta individu yang terlibat dengan pelancongan untuk mengubah corak pekerjaan kepada menangkap ikan dan menoreh getah. Selain itu, kegiatan perlombongan bijih besi yang intensif, kekurangan sumber hutan (buah-buahan, haiwan dan ikan), telah menjadikan kawasan hutan dan tasik di sekitar Tasik Chini bukan lagi merupakan tempat yang sesuai untuk berkelah bersama ahli keluarga sambil mencari rezeki. Ketiadaan hutan juga bermakna penduduk terpaksa beralih kepada ekonomi lain untuk menampung kehidupan mereka. Malah, terdapat beberapa kelompok dalam kalangan komuniti Jakun yang kecewa terhadap program Man and Biosphere yang dirasakan gagal melindungi dan membantu komuniti setempat untuk menjaga persekitaran dan keindahan Tasik Chini daripada kesan pembalakan dan perlombongan. Ini kerana, penurunan kualiti air Tasik Chini dan kemusnahan tumbuh-tumbuhan akuatik semenjak 20 tahun yang lalu (Zati Sharip \& Juhaimi Jusoh, 2010; Mohd Shuhaimi Othman \& Lim, 2004) masih lagi menjadi isu sehingga kini. 
Jadual 4. Fungsi Tasik dan kawasan hutan tahun 2017

\begin{tabular}{lcccc}
\hline & \multicolumn{3}{c}{ Sumber } \\
\cline { 2 - 4 } Jenis keperluan/perolehan aktiviti & \multicolumn{2}{c}{ Tasik/Sungai } & Hutan \\
\cline { 2 - 5 }$(\boldsymbol{\Sigma} \mathbf{n}=\mathbf{4 5})$ & $\begin{array}{c}\text { Tidak } \\
\text { pernah }\end{array}$ & $\begin{array}{c}\text { Ya } \\
(\mathbf{\%})\end{array}$ & $\begin{array}{c}\text { Tidak } \\
\text { pernah } \\
(\mathbf{\%})\end{array}$ & $\begin{array}{c}\text { Ya } \\
(\boldsymbol{\%})\end{array}$ \\
\hline Bekalan hasil kraftangan & 90.91 & 9.09 & 89.72 & 10.28 \\
Sumber pekerjaan berkait pelancongan & 84.16 & 15.84 & 79.11 & 20.89 \\
Sumber rekreasi /hiburan & 70.82 & 29.18 & 84.81 & 15.19 \\
\hline
\end{tabular}

Sumber: Data kerjalapangan di Kampung Melai, Cendahan dan Puput, 2017

\section{Kepelbagaian aktiviti pelancongan}

Selain sajian keindahan alam sekitar, penganjuran pelbagai aktiviti yang boleh menarik minat pelancong juga amat penting supaya para pengunjung tidak berasa bosan dan ingin mengenali, mendalami serta menghabiskan masa ke atas aktiviti yang disarankan. Apa yang membimbangkan, aktiviti pelancongan di Tasik Chini adalah sangat terhad dan kurang kepelbagaian. Selain pelancong akademik yang datang untuk mendalami ilmu sains dan alam sekitar di bawah pendekatan pelancongan pendidikan di Wilayah Ekonomi Pantai Timur (ECER) (Siti Kasmera Ariffin et al., 2016), aktiviti pelancongan hanya tertumpu kepada tiga program utama iaitu penjelajahan tasik dengan menaiki bot, lawatan kebudayaan di Kampung Cendahan dan Tanjung Puput serta aktiviti jungle trekking yang ditawarkan oleh Rajan Jones Guest House dan juga Lake Chini Resort. Ketiga-tiga siri lawatan ini bukan sahaja dapat dilakukan dalam tempoh masa satu hari malah dalam beberapa jam sahaja. Pada masa kini, aktiviti jungle trekking di sesetengah kawasan misalnya di Kampung Melai tidak dapat dijalankan lagi disebabkan oleh kemusnahan hutan kesan daripada aktiviti pembalakan. Oleh itu, program pelancongan di Tasik Chini ini kurang berjaya menarik minat para pelancong untuk berkunjung sekali lagi di Tasik Chini.

Pemerhatian semasa lapangan mendapati aktiviti memancing di sekitar Tasik Chini hanya melibatkan pelancong tempatan terutamanya pelancong harian yang menetap tidak jauh daripada kawasan Tasik Chini. Jika dahulu, Tasik Chini merupakan syurga bagi mereka yang gemarkan aktiviti memancing (Wavell, 1988) namun ia telah berubah semenjak pembinaan kincir air dan kemerosotan alam sekitar di Tasik Chini. Antara alasan yang diterima daripada para pemancing tempatan yang berkunjung ke sini adalah kurangnya ikan yang bersaiz besar dan kualiti ikan yang rendah. Pencemaran air juga telah menyebabkan ikan air tawar di kawasan Tasik Chini ini berbau lumpur dan hanyir. Walaupun begitu, aktiviti memancing oleh penduduk Jakun di sekitar Tasik Chini masih lagi giat dijalankan bagi menampung keperluan harian.

Penjualan produk kraftangan penduduk Tasik Chini atas talian melalui 11street seperti pribumi akar serapat Tasik Chini, bakul anyaman mengkuang pribumi Tasik Chini, beg anyaman mengkuang pribumi Tasik Chini dan buku pribumi Tasik Chini juga adalah salah satu promosi yang baik untuk penjualan kraftangan dan produk penduduk Jakun di Tasik Chini. Ini dilakukan melalui usaha sama di antara agensi kerajaan seperti Kementerian Komunikasi dan Multimedia Malaysia, Pusat Penyelidikan Tasik Chini (PPTC UKM) dan komuniti (Produk Orang Asli, 2018). 


\section{Pembangunan infrastruktur dan kemudahan asas}

FELDA Chini dihubungkan dengan bandar-bandar utama seperti Kuantan, Pekan dan Muadzam Shah melalui penyediaan bas Mara Liner yang diselenggara oleh badan kerajaan. Namun begitu, terminal bas FELDA Chini ini terletak agak jauh dari perkampungan Orang Asli Tasik Chini dengan jarak perjalanan melebihi 10 kilometer. Pelancong perlu mengambil teksi atau kereta sewa yang disediakan oleh penduduk Melayu di FELDA Chini. Namun begitu, pelancong sering mengalami kesukaran mendapatkan teksi di sekitar FELDA Chini kerana jumlah yang sangat terhad serta tindakan pemandu teksi yang ada kalanya mengambil kesempatan dengan mengenakan tambang yang tinggi. Perkhidmatan bas yang kurang efektif juga menyukarkan akses pelancong ke Tasik Chini. Melalui inisiatif kerajaan dalam membangunkan penempatan komuniti Orang Asli, kemudahan infrastruktur seperti dewan balai raya yang dilengkapi dengan kemudahan tandas telah dibangunkan, namun begitu kemudahan infrastruktur ini terhad kepada penggunaan komuniti Jakun di Tasik Chini sahaja.

\section{Suntikan modal dan promosi}

Kajian ini mendapati, modal yang rendah dan kekurangan kemudahan asas menyebabkan aktiviti pelancongan terutamanya rumah penginapan yang diusahakan oleh komuniti Jakun Tasik Chini hambar dan kurang daya tarikan. Komuniti ini tidak mampu bersaing dengan Lake Chini Resort yang mempunyai kemudahan yang jauh lebih baik seperti kemudahan air yang bersih, penginapan berhawa dingin, tempat makan, tandas dan bot. Sehingga kini, kebanyakan pelancong yang menginap di Tasik Chini adalah rata-ratanya terdiri daripada pelancong luar negara yang gemarkan aktiviti lasak dan juga mendapatkan maklumat mengenai kewujudan Rajan Jones Guest House melalui internet. Kebiasannya, pelancong tempatan akan memilih untuk tinggal di kawasan petempatan Melayu FELDA Chini atau pun Lake Chini Resort yang mempunyai kemudahan makanan yang berhampiran.

Kurangnya risalah yang menjelaskan perubahan ekosistem tasik semulajadi juga menyebabkan pengunjung sentiasa mengharapkan kesempurnaan Tasik Chini sepanjang musim. Misalnya keluhan pelancong yang ingin melihat bunga teratai namun tidak dapat berbuat demikian kerana kelompok teratai yang tumbuh secara semulajadi di sekitar Tasik Chini musnah disebabkan oleh banjir boleh menjadi hambatan dalam pemasaran eko-pelancongan. Kegagalan untuk menyampaikan maklumat yang sebenar, jelas dan terkini sama ada melalui risalah atau laman sesawang juga akan menyusahkan dan menyebabkan para pelancong membuat jangkaan yang tidak tepat. Oleh itu, pelancongan berunsurkan pendidikan juga penting bagi meningkatkan kesedaran para pelancong tentang budaya komuniti setempat serta program penjagaan dan pemuliharaan yang dilakukan di Tasik Chini (Siti Kasmera Ariffin et al., 2016)

Oleh itu, pelancongan budaya yang mendukung konsep Homestay dan Kampungstay perlu diperkenalkan kepada komuniti Orang Asli di Tasik Chini bagi mengalihkan jangkaan kesempurnaan alam sekitar di Tasik Chini oleh sebilangan pelancong luar. Dalam konsep Homestay dan Kampungstay ini (Khairul Hisyam Kamarudin, 2018; Daisy Igang, 2018), fokus utama yang terarah kepada kehidupan komuniti Jakun dalam persekitaran mereka dan juga aktiviti tambahan lain seperti tarian Kelundang, aktiviti menganyam, aktiviti mencari ikan dan sebagainya boleh disusun semula bagi menarik perhatian para pelancong untuk datang berkunjung. Promosi pelancongan berasaskan Homestay dan Kampungstay ini boleh dilakukan melalui kerjasama dengan JAKOA dan Kementerian Pelancongan bagi menggantikan konsep 
eko-pelancongan berasaskan keindahan tasik dan hutan yang semakin meruncing. Ini bagi meningkatkan semula semangat penduduk kampung yang masih mahu mengekalkan keindahan persekitaran mereka dan juga terlibat dalam pelancongan. Ia juga dapat menjana semula pendapatan tambahan penduduk berasaskan eko-pelancongan.

\section{b. Kesiapsiagaan Komuniti Jakun}

Komuniti Jakun Tasik Chini telah menyedari kepentingan pelancongan sebagai salah satu aktiviti yang boleh menjana pendapatan mereka. Penglibatan mereka dalam pekerjaan yang menjurus kepada perkhidmatan seperti penubuhan chalet atau rumah tumpangan sendiri misalnya Wira Gumum Resorts seperti yang dibincangkan sebelum ini dilihat sebagai satu usaha yang sangat positif. Ini menunjukkan komuniti Orang Asli juga mempunyai aspirasi dan keinginan untuk maju ke hadapan. Walaupun begitu, kemahiran yang rendah dalam pengurusan perniagaan (dari sudut kebersihan, kreativiti dan perkhidmatan yang mesra pelanggan), ketidakmampuan untuk menguasai bahasa asing seperti Bahasa Inggeris dan ketidakmampuan untuk menilai keperluan pasaran merupakan punca utama kegagalan operasi rumah tumpangan ini.

Selain penglibatan dalam perniagaan yang menyediakan penginapan, pemandu pelancong merupakan pekerjaan kedua yang diceburi oleh komuniti Jakun di Tasik Chini. Di samping mengambil upah bekerja sebagai pemandu pelancong yang dianjurkan oleh Lake Chini Resort, penduduk kampung juga telah bekerjasama dengan pemilik rumah penginapan Rajan Jones Guest House untuk mengendalikan aktiviti menaiki bot di sekitar Tasik Chini secara persendirian. Walaupun begitu, penglibatan mereka ini tidak begitu teratur dan bersistematik kerana bergantung sepenuhnya kepada ekonomi bermusim disamping kemudahan bot dan jadual masa yang tidak menentu. Oleh itu, agak sukar untuk pelancong membuat tempahan mengikut masa yang mereka perlukan. Ini menunjukkan, komuniti Jakun di Tasik Chini masih belum peka dengan limitasi masa lawatan pelancong yang singkat yang perlu dititikberatkan oleh individu dan kelompok yang terlibat dalam menguruskan program pelancongan. Kesukaran untuk mendapatkan pemandu bot bagi mengelilingi Tasik Chini akan menghalang pelancong daripada menikmati keindahan sebenar Tasik Chini yang telah dipromosikan dan sekaligus mengurangkan salah satu daripada tiga aktiviti rekreasi yang ditawarkan di Tasik Chini. Pengurangan aktiviti rekreasi ini akan memendekkan lagi jangka masa kunjungan para pelancong dan tidak menguntungkan penduduk setempat.

Harga yang ditetapkan kepada pelancong yang menaiki bot untuk melihat keindahan di sekitar tasik adalah di antara RM80-RM120 bagi sebuah bot. Kadar harga ini tidak mempunyai perbezaan ketara semenjak beberapa tahun yang lalu di mana bayaran RM70-120 telah dikenakan untuk sekali perjalanan bagi sekumpulan enam hingga lapan orang pelancong (Mustaffa Omar, 2005). Walaupun begitu, kadar harga ini tidak sesuai bagi pelancong persendirian yang mempunyai bajet yang rendah (bag-pack traveller) dan masa yang terhad. Selain itu, penurunan aktiviti pelancongan juga telah menyebabkan seorang individu untuk bertindak membuka perniagaan yang berunsurkan hiburan, yakni karoke atau menyanyi dengan alunan muzik yang kuat sehingga lewat malam untuk tujuan menjana pendapatan. Karoke ini terletak berhampiran dengan Rajan Jones Guest House yang memberi kesan ke atas aktivit pelancongan di kawasan tersebut. 


\section{c. Hakmilik tanah}

Hakmilik tanah merupakan satu keperluan sekiranya komuniti Jakun ingin bergiat aktif dalam kegiatan eko-pelancongan di kawasan ini. Sehingga kini, tiada status hakmilik kekal mahu pun rizab perkampungan diberikan dalam mana-mana kawasan tanah petempatan dan pertanian komuniti Jakun di Tasik Chini. Pembangunan rumah penginapan sukar dilaksanakan jika komuniti Jakun tidak mempunyai hakmilik yang kekal ke atas tanah tersebut. Meskipun penduduk setempat memiliki tanah sebagai rizab perkampungan, Akta 134 (Akta Orang Asli, 1954), Seksyen 9-13 membenarkan mana-mana rizab Orang Asli yang diwartakan untuk diambil alih atas nama pembangunan. Oleh itu walaupun tanah di Tasik Chini dirizabkan, tetapi kerajaan boleh mengambil alih tanah perkampungan tersebut pada bila-bila masa dengan membuat bayaran pampasan berdasarkan pokok buah-buahan. Akta ini tidak memasukkan apa-apa elemen seperti kehilangan perniagaan dalam pampasannya. Salah satu masalah yang dilihat di sini ialah letakan kampung Orang Asli biasanya di bawah tanah kerajaan.

\section{Kesimpulan}

Kajian ini menunjukkan bahawa terdapat usaha yang dilakukan oleh komuniti Jakun dalam menyertai aktiviti pelancongan termasuk penglibatan aktif dalam persatuan pemuliharaan dan pemeliharaan alam sekitar sejak tahun 1990an. Ini menunjukkan terdapatnya kesediaan komuniti Orang Asli untuk beralih daripada ekonomi tradisi kepada ekonomi berasaskan perkhidmatan disebabkan oleh persekitaran ekonomi yang berubah. Namun, kemerosotan alam sekitar disebabkan oleh pembalakan dan perlombongan telah memberi kesan yang besar ke atas keupayaan Tasik Chini untuk menjadi salah satu destinasi ekopelancongan yang terkenal di Malaysia. Meskipun program Man and Biosphere di bawah UNESCO telah diperkenalkan pada tahun 2009 di Tasik Chini, namun kewujudan program ini tidak dapat menangani kemerosotan alam sekitar yang masih berterusan sehingga kini. Kegagalan untuk menjaga dan memulihara keindahan persekitaran Tasik chini bukan sahaja telah mengubah halatuju para pelancong ke kawasan yang lain, malah menyebabkan pembaziran daripada aspek peruntukan kewangan bagi penyediaan kemudahan infrastuktur dan prasarana yang telah disediakan oleh kerajaan untuk membangunkan semula Tasik Chini bagi tujuan eko-pelancongan secara lestari di bawah pembangunan Wilayah Ekonomi Pantai Timur (ECER). Pada masa kini, pergantungan komuniti Jakun kepada masyarakat luar dalam menentukan halatuju ekonomi pelancongan adalah sangat tinggi disebabkan oleh ketiadaan modal kewangan, kemahiran yang kurang (penguasaan bahasa dan pengurusan perniagaan), promosi pelancongan yang rendah dan ketidakupayaan mereka untuk menghalang kemerosotan alam sekitar di Tasik Chini yang berterusan. Justeru, konsep Indigenous eco-tourism tidak mungkin dapat dilaksanakan sekiranya keindahan alam sekitar di kawasan Tasik Chini semakin musnah, disamping kepelbagaian dan keunikan produk budaya yang dihasilkan oleh penduduk Jakun tidak dapat diteroka dengan sepenuhnya disebabkan ketiadaan perlindungan atau jaminan kekal ke atas tanah yang diusahakan untuk aktiviti pelancongan. Oleh itu, salah satu penyelesaian terbaik bagi menyahut cabaran pembangunan ekonomi dalam Rancangan Malaysia Kesebelas adalah mewujudkan ekonomi berteraskan pelancongan yang kreatif berasaskan rekreasi dan sukan serta pelancongan berasaskan konsep homestay dan kampungstay yang dipacu oleh komuniti (community based rural tourism). 
Selain itu, penglibatan komuniti Jakun dalam penjagaan dan pemuliharaan alam sekitar adalah sangat penting bagi memastikan kesinambungan sumber semulajadi ini di Tasik Chini. Mempakejkan semula Tasik Chini sebagai salah satu destinasi pelancongan yang bersesuaian dengan alam semulajadi seperti aktiviti lasak dan pendidikan alam sekitar merupakan salah satu cara yang baik untuk menarik pelancong dan pengusaha dari dalam dan luar negara. Ini tidak dapat dilakukan sendiri oleh komuniti Jakun yang menetap di Tasik Chini disebabkan jaringan dan pengalaman mereka dalam mengendalikan pelancongan global yang sangat terhad. Kerjasama dengan Lake Chini Chini Resort, Pusat Penyelidikan Tasik Chini, Jabatan Kemajuan Orang Asli (JAKOA) dan Kementerian Pelancongan dan Kebudayaan Malaysia dalam pengendalian dan pengagihan aktiviti pelancongan, serta pemasaran produk tempatan amat penting bagi mengurangkan ketidakupayaan persaingan disebabkan akses kepada kemudahan asas dan infrastruktur. Oleh itu, penilaian program-program berkaitan penjagaan dan pemuliharaan alam sekitar di sekitar kawasan Tasik Chini perlu dilakukan semula dengan mengambilkira idea dan keputusan semua pihak termasuk komuniti Jakun bagi meningkatkan dan menjayakan eko-pelancongan yang berasaskan komuniti di Tasik Chini.

\section{Rujukan}

Ainon Hamzah \& Yanti Hattasrul (2009). Water quality and microbiological study at Tasik Chini, Pahang. Dlm Mushrifah Idris, Mohammad Shuhaimi Othman, Sahibin Abd. Rahim, Khatijah Hj. Hussin \& Nur Amelia Abbas (pnyt.). Sumber asli Tasik Chini: Ekspedisi saintifik. Fakulti Sains dan Teknologi, Universiti Kebangsaan Malaysia.

Daisy Igang. (2018) Pengurusan Kampungstay Orang Asli: Homestay Bakun Sg. Asap, Belaga Sarawak, Seminar eko-pelancongan Orang Asli, 7-10 November, Hotel Impiana, Perak.

Gezon, L. L. (2004) Who wins and who loses? Unpacking the "local people" concept in ecotourism: a longitudinal study of community equity in Ankarana, Madagascar. Journal of Sustainable Tourism, 2 (5): 821-838

Gomes, A. (1989). Things are not what they seem: Semai economy in the 1980s. Akademika 35: 47-54

Harris, C. C. (2005). The role of ecotourism in Aboriginal community development: the case of Lennox Island First Nation. The degree of master of recreation management, Acadia University, Canada.

Khairul Hisyam Kamarudin. (2018) Faktor Kejayaan Program pelancongan Luar Bandar Dipacu Komuniti (Kampungstay) Orang Asli, Seminar eko-pelancongan Orang Asli, 7-10 November, Hotel Impiana, Perak.

Mokbolhassan, H. K. (2014). Managing Tasek Bera: Department of Wildlife and National Parks and local community participation. Journal of Wildlife and Parks, 27 : 121-127

Muhammad Barzani Gasim, Mushrifah Idris, Sahibin Abd Rahim, Mohd Shuhaimi Othman \& Shaharudin Idrus. 2009. The impact of physical activities in the Tasik Chini: a preliminary study. Dlm. Mushrifah Idris, Mohammad Shuhaimi Othman, Sahibin Abd Rahim, Khatijah Hj Hussin \& Nur Amelia Abas (pnyt.). Sumber Asli Tasik Chini: Ekspedisi Saintifik. Hlm. 55-63. Bangi: Universiti Kebangsaan Malaysia.

Mustaffa Omar. (2005). Dampak pembangunan ekopelancongan dan pertanian ke atas kehidupan komuniti Orang Asli. Dlm. Mushrifah Idris, Khatijah Hussin \& Abdul Latiff Mohamad (pnyt.). Sumber asli Tasik Chini. Bangi: Penerbit Universiti Kebangsaan Malaysia. 
Mohd Shuhaimi Othman \& Lim E. C. (2004). Keadaan Eutrofikasi di Tasik Chini, Pahang. Dlm talian http://pkukmweb.ukm.my/ penerbit/jurnal_pdf/SM35\%282\%29-05-keadaan.pdf

Mohd Shuhaimi Othman, Lim E. C., Mushrifah Idris \& Ahmad Abas Kutty (2009). Kepekatan logam berat dalam air dan sedimen tasik dan sungai. Dlm Mushrifah Idris, Mohammad Shuhaimi Othman, Sahibin Abd. Rahim, Khatijah Hj. Hussin \& Nur Amelia Abbas. Sumber asli Tasik Chini: Ekspedisi saintifik. Fakulti Sains dan Teknologi, Universiti Kebangsaan Malaysia.

Kementerian Hal Ehwal Ekonomi. 2018. Ringkasan Eksekutif Kajian separuh Penggal Rancangan Malaysia Kesebelas 2016-2020: Keutamaan dan penekanan baru.

Produk Orang Asli Chini di Pribumi Mall. (2018, 20 Oktober). Sinar Harian. Dlm talian http://www.sinarharian.com.my/bisnes/produk-orang-asli-chini-di-pribumi-mall1.894252

Siti Kasmera Ariffin, Habibah Ahmad, Hamzah Jusoh, Mohd Ekhwan Toriman, Sri Winarni Samsir, Mushrifah Idris (2016). Pendekatan strategik dalam pelancongan pendidikan di destinasi ekopelancongan di Wilayah Ekonomi Pantati Timur (ECER). Malaysian Journal of Society and Space, 12 (12): 25-39.

Wavell S. (1988). The Naga King's Daughter. Kuala Lumpur: Antara Book Company.

Strategik Implementation Plan Comprising of Integrated Management Plan and Gazettement of Tasik Chini State Park, Pekan Pahang Volume 3 (2010). Baseline Data and Strategic Environmental Assessment. Bangi: East Cost Economic Region; UKM Pakarunding

Sustainable Development Network Malaysia. 2007. Dedicated to promoting sustainable development through environmental stewardship. Dlm talian http://rcse.edu.shigau.ac.jp/gov-pro/plan/2009list/05lake_chini/malaysian_presentations/06_susden_chini_ profile_ppt_2-3_aug.2007.pdf

Zanisah Man, Nurul Fatanah Zahari \& Mustaffa Omar. (2009). Kesan ekonomi pelancongan terhadap komuniti Batek di Kuala Tahan, Pahang. Journal e-Bangi, 4 (1): 1-12

Zanisah Man \& Sharina Halim. 2018. Coping with Changes: The Reconstruction of Place and Identity Among the Batek in Taman Negara, Pahang, Malaysia, paper presented at The Twelfth International Conference on Hunting and Gathering Societies (CHAGS 12), 2327 July

Zati Sharip \& Juhaimi Jusoh. 2010. Integrated lake basin management and its importance for Lake Chini and other lakes in Malaysia. Lakes and Reservoires: Research Management, 15:41-51

Zeppel, H. D. (2006). Indigenous Ecotourism: sustainable development and management. CAB International 